\title{
CAN SHELTERWOOD LOGGING MAINTAIN HERB LAYER DIVERSITY IN A BEECH FOREST IN TURKEY?
}

\author{
YILMAZ, O. Y. ${ }^{*}-$ YILMAZ, H. $^{2}$ \\ ${ }^{1}$ Department of Surveying and Cadastre, Faculty of Forestry, Istanbul University-Cerrahpaşa, \\ Istanbul 34473, Turkey \\ ${ }^{2}$ Ornamental Plant Cultivation Program, Vocational School of Forestry, Istanbul University- \\ Cerrahpaşa, Istanbul 34473, Turkey \\ (phone: +90-212-338-2400; fax: +90-212-338-2428) \\ *Corresponding author \\ e-mail: yilmazy@istanbul.edu.tr; phone: +90-212-338-2400; fax: +90-212-226-1113 \\ (Received $9^{\text {th }}$ Sep 2019; accepted $15^{\text {th }}$ Nov 2019)
}

\begin{abstract}
The abundance and diversity of forest understory vegetation can be significantly impacted by forest management. Besides having a wide geographical distribution in Turkey, the Oriental beech (Fagus orientalis Lipsky) is also one of the economically important timber species of the country. The aim of this study is to compare the understory herb layer communities of mature and young beech stands which regenerated as a result of the shelterwood method. We studied understory plant species diversity and composition in 16 plots in old and young beech stands in Belgrad Forest near İstanbul, Turkey. We found no significant differences between the two stand types in understory plant diversity but understory species compositions in two stand types were found to be different. Our finding can be useful for forest management planning; by focusing on stand scale to achieve forest management conserving understory plant diversity in a forest.
\end{abstract}

Keywords: Belgrad Forest, understory composition, indicator species, pure beech stands, stand age

\section{Introduction}

Herb layer vegetation is an important component for biodiversity conservation efforts because it contains the majority of vascular plant species diversity and plays a significant role in forest ecosystem functioning (Augusto et al., 2003; Lorenz et al., 2006; Gilliam, 2007; Ellum, 2009). Maintenance of biological diversity during timber harvesting and successful regeneration of forest tree species has gained importance as an issue for sustainable forest management. Investigating the potential effects of silvicultural treatments on the future plant species diversity in forests is crucial for the improvement of effective management strategies to achieve sustainable forest ecosystems (Roberts and Gilliam, 1995; Lindenmayer and Franklin, 2002; Ellum, 2009; Y1lmaz et al., 2018). Past and present human activities and natural disturbances are a major factor affecting the composition and diversity of plant species in a forest (Elliott et al., 1997; Stefańska-Krzaczek et al., 2019). Forest management practices lead to changes in species composition, age structure, and vertical stratification of tree layer and also indirectly affect understory microclimate, light availability, litter and soil properties in a forest. These forest understory conditions can also impact the diversity and composition of the herb layer (Paillet et al., 2011). Different forest management operations are applied throughout the life of the forest from regeneration to harvesting. Therefore, it is necessary to ascertain the impact of different silvicultural practices on understory plant composition and diversity (Hunter, 1999; Barbier et al., 2008; Durak, 2012). 
Oriental beech is one of the major broadleaved forest trees in Turkey. Oriental beech forests cover 1899929 hectares and comprise about $8.5 \%$ of the forestland in Turkey (OGM, 2015). The oriental beech is commonly distributed in the northern region of Turkey and it is also scattered in western and southern parts of the country. This species can form pure stands; however, more frequently it mixes with broadleaved and conifer trees such as oak (Quercus sp.), hornbeam (Carpinus betulus L.), chestnut (Castanea sativa Mill.), fir (Abies sp.), Anatolian blackpine (Pinus nigra Arnold), Scots pine ( $P$. sylvestris L.), oriental spruce (Picea orientalis (L.) Link.) between (30) 700-1300 (2000) $\mathrm{m}$ in Turkey (Yaltırık, 1982; Y1lmaz, 2014).

The present study examined effects of shelterwood silvicultural method practices on herb layer composition and diversity in beech forests. Our main purpose was to investigate patterns in herb layer plant species diversity in response to two levels of stand age and structure. We compared mature and naturally regenerated young oriental beech stands with regards to stand structural features, understory richness and composition in Belgrad Forest to understand how the stand age and stand structure influences understory plant diversity.

\section{Materials and methods}

\section{Study area}

The study was conducted in the Belgrad Forest of İstanbul, 28 $54^{\prime} 25^{\prime \prime}-28^{\circ} 56^{\prime} 37^{\prime \prime} \mathrm{E}$, $41^{\circ} 13^{\prime} 00^{\prime \prime}-41^{\circ} 14^{\prime} 13^{\prime \prime} \mathrm{N}$ in Turkey (Fig. 1), a region with humid, mesothermal and maritime climate. Annual mean precipitation is about $1091 \mathrm{~mm}$ and annual mean temperature is about $12.8^{\circ} \mathrm{C}$ (Özhan et al., 2010). Soils in the region are loamy clay and are developed mainly from carboniferous clay schists and neogene deposits (Balci et al., 1986). The forest covers 5900 ha, elevation ranges from about 45 to $230 \mathrm{~m}$ a.s.l.

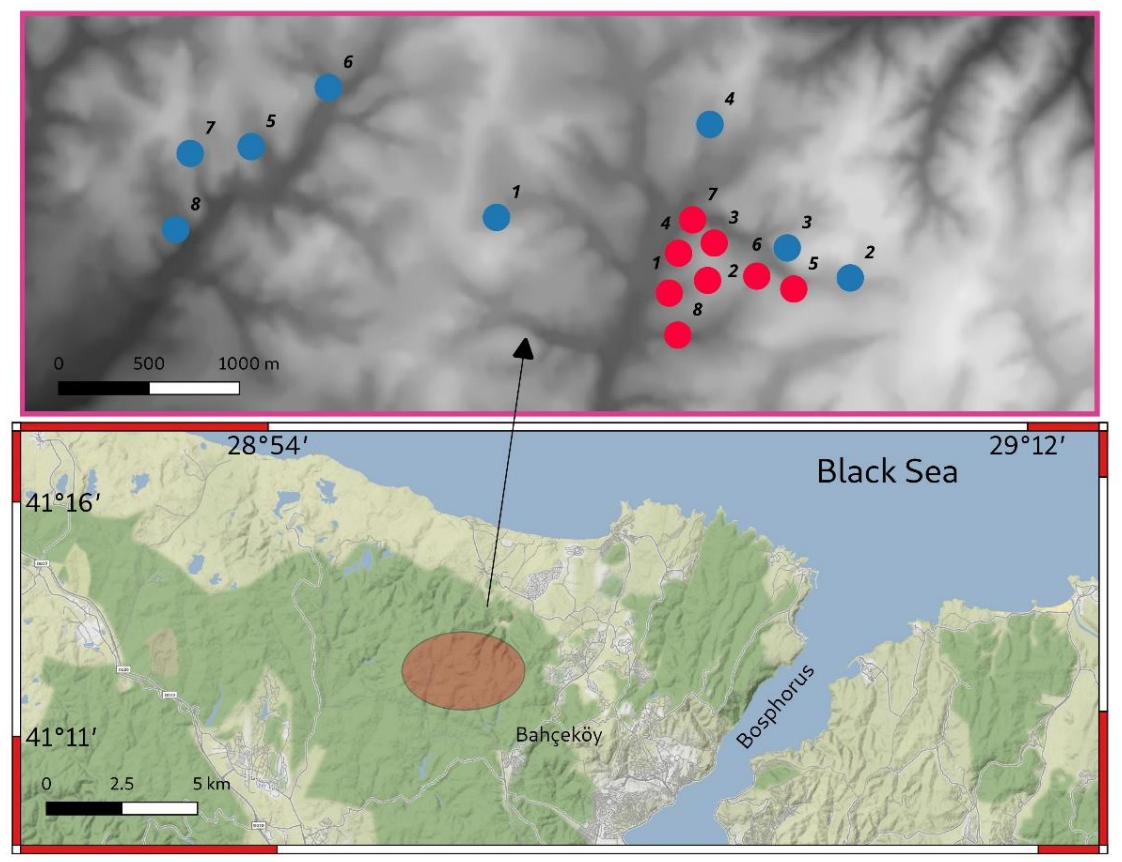

Figure 1. The study area within the Belgrad Forest, İstanbul (bottom). The sampling plots of beech stands are represented by circles (top) which are color coded based on the stand's development stage (blue: mature beech stands, red: young beech stands) 
The Belgrad Forest is an old preserved mixed deciduous forest ecosystem. The natural forest is composed of oak species (Quercus petraea (Mattushka) Liebl., Quercus frainetto Ten., Q. cerris L.), oriental beech (Fagus orientalis), chestnut (Castanea sativa) and European hornbeam (Carpinus betulus) with minor occurence of aspen (Populus tremula L.), common alder (Alnus glutinosa L.), field maple (Acer campestre L.) and field elm (Ulmus minor Mill.) (Yaltırık, 1966).

Pure oriental beech stands occupy the northwest and western slopes with an inclination of 10-40\%, and are spread over the sandy loamy and loamy soils, the pH values of which vary from 4.4 to 5.8 in Belgrad Forest (Yaltırık et al., 1983). The beech stands in Belgrad Forest have been managed under the uniform shelterwood silvicultural method since 1959 (Saatçioğlu, 1970). Uniform shelterwood method used to regenerate an even age stand with multiple cuts to help shelter new establishment. Existing partial canopy which serves to modify understory conditions, create a favorable environment for reproduction, and provide a seed.

\section{Vegetation data}

A total of sixteen $20 \mathrm{~m} \times 20 \mathrm{~m}$ permanent sample plots, 8 in naturally regenerated young beech stands (YB) and 8 mature beech stands (MB), were established in pure even aged beech forests in comparable site conditions in 2017. The sample plots were laid out in a homogenous and representative area located in each stand minimum $250 \mathrm{~m}$ far away each other to overcome spatial autocorrelation. Trees with a diameter at breast height $(\mathrm{dbh}) \geq 8 \mathrm{~cm}$, taken in two perpendicular directions, were measured. Tree density and basal area were estimated for each quadrat (Table 1).

Table 1. Stand structural variables for the 16 plot in beech stands $(\mathrm{dbh}=1.3 \mathrm{~m}, \mathrm{YB}=$ young beech stands, $M B=$ mature beech stands)

\begin{tabular}{|c|c|c|c|c|}
\hline & Mean dbh (cm) & St. dev. dbh (cm) & Number of stem $\left(h^{-1}\right)$ & Basal area $\left(\mathrm{m}^{2} \mathrm{ha}^{-1}\right)$ \\
\hline \multicolumn{5}{|c|}{ MB } \\
\hline MB1 & 57.66 & 24.18 & 175 & 57.66 \\
\hline MB2 & 35.42 & 19.68 & 350 & 44.38 \\
\hline MB3 & 37.00 & 11.23 & 425 & 49.65 \\
\hline MB4 & 44.85 & 13.19 & 225 & 38.28 \\
\hline MB5 & 34.09 & 19.85 & 275 & 32.84 \\
\hline MB6 & 28.79 & 16.79 & 400 & 34.34 \\
\hline MB7 & 46.00 & 25.41 & 250 & 52.95 \\
\hline MB8 & 42.15 & 16.36 & 350 & 55.67 \\
\hline Average & 40.75 & 18.34 & 306.25 & 45.09 \\
\hline \multicolumn{5}{|c|}{ YB } \\
\hline YB1 & 19.35 & 4.00 & 950 & 29.10 \\
\hline YB2 & 18.28 & 3.92 & 1025 & 28.12 \\
\hline YB3 & 16.23 & 4.56 & 900 & 20.06 \\
\hline YB4 & 16.09 & 4.11 & 975 & 21.08 \\
\hline YB5 & 16.10 & 4.81 & 1125 & 24.90 \\
\hline YB6 & 18.21 & 3.79 & 1000 & 27.13 \\
\hline YB7 & 14.00 & 5.27 & 950 & 16.64 \\
\hline YB8 & 13.85 & 3.68 & 1275 & 20.54 \\
\hline Average & 16.51 & 4.27 & 1025 & 23.45 \\
\hline
\end{tabular}


Four $1 \mathrm{~m} \times 1 \mathrm{~m}$ subplots were established at the corners of each plot to sample the herb layer. Vegetation surveys in each subplot were carried out during the main growing season (May-June) to avoid vegetation bias. All herb layer species were identified in whole plot area and cover of each species was estimated separately in four subplots with the ordinal scale of Braun Blanquet (1964). All herbaceous plants, ferns, seedling and saplings with a height of less than $50 \mathrm{~cm}$ were considered as herb layer. The nomenclature of vascular plants follows the Flora of Turkey (Davis, 1965-1980).

\section{Statistical analysis}

To investigate the interactions between stand development stage and herb layer, the data set was prepared and organized before performing statistical analysis. Community tables were created in two different data sets. Presence/absence data set (hereafter PADS $)$ is the presence/absence of species in the 4 subplots $(1 \mathrm{~m} \times 1 \mathrm{~m})$, and species identified in the each $20-\mathrm{m} \times 20-\mathrm{m}$ permanent plot. Abundance data set (hereafter ADS) is the average abundance of species in the 4 subplots. A table indicating the development stage of the stands was produced as the environmental data set (hereafter EDS).

Diversity indices (richness, abundance, Shannon, Simpson) were calculated using the two data sets which were previously prepared and organized. The species richness was expressed as the number of herb-layer species for the PADS and was compared between successional stages of beech stands using species accumulation curves. The rankabundance curves of ten most abundant plants was created from the ADS. Permutational multivariate analysis of variance (PERMANOVA) was used to compare the similarity of these two stand types (MB and YB). 'vegan' (Oksanen et al., 2019) and 'BiodiversityR' (Kind and Joe, 2005) packages of the R 3.0.1 (R Development Core Team, 2017) were used for the analysis.

As a measure of species diversity and dominance/abundance, accumulation curves (Kindt and Coe, 2005) were constructed. An indicator species analysis was executed to reveal the relationship between the herb layer species and the overstory composition (Dufrêne and Legendre, 1997) using the R package "indicspecies" (De Cáceres and Jansen, 2013).

\section{Results and discussion}

In this study, we were interested in comparing understory species composition and richness of two different succession stages of beech stands. Predicting the response of forest understory plants to disturbances caused by timber harvest or other silvicultural interventions is important to implement silvicultural practices focusing on the conservation of all components of forest ecosytems (Ellum, 2009). Results of the study clearly indicated that overstory structure and age shaped understory species composition in young and old even-aged beech forests.

\section{Stand characteristics}

Mean diameter at breast height and basal area of mature beech stands were $40.75 \mathrm{~cm}$ and $45.09 \mathrm{~m}^{2} / \mathrm{ha}^{-1}$ while in young beech stands, they were $16.51 \mathrm{~cm}$ and $23.45 \mathrm{~m}^{2} / \mathrm{ha}^{-1}$, respectively (Table 1). The average number of trees was 306 in mature beech stands and 1025 in young beech stands. While the mean diameter of the breast height and the basal 
area of mature beech stands are about twice as large as those of young beech stands, the number of trees in young stands is three times the amount in mature stands. According to these mean diameter values, the stands are in pole and mature development stage.

\section{Diversity and abundance of understory herb layer}

64 vascular plant species were identified in the understory of beech stands. 45 species occurred in young beech stands and 49 species were also found in mature stands (Table 2). All the species recorded were native in old beech stands but one non-native species was found in young beech stands (Table Al in the Appendix). Of the species recorded, while 19 species are unique to mature beech stands, 15 species are unique to young stands. Mean species richness was found same within the two stand types as 20.25. Epimedium pubigerum (DC.) C. Morren \& Decne. was the most abundant species in all quadrats of young and mature beech stands (Fig. 3). İster and Gökbulak (2009) compared the species diversity of the herbaceous plants in the beech and oak stands in the same study area, and they identified 12 herbaceous plant species in 3 beech stands using transect sampling method.

Table 2. Diversity indices of the mature and young beech stands $(Y B=$ young beech stands, $M B=$ mature beech stands, $P A D S=4$ subplots plus whole plot area data, ADS = the average of 4 subplots data)

\begin{tabular}{c|c|c|c|c|c|c}
\hline \multicolumn{2}{l|}{} & $\begin{array}{c}\text { Richness } \\
\text { (abundance) }\end{array}$ & $\begin{array}{c}\text { Mean } \\
\text { richness }\end{array}$ & $\begin{array}{c}\text { St. dev. of } \\
\text { richness }\end{array}$ & $\begin{array}{c}\text { Shannon } \\
\text { index }\end{array}$ & $\begin{array}{c}\text { Simpson } \\
\text { index }\end{array}$ \\
\hline \multirow{2}{*}{ PADS } & MB & 49 & 20.25 & 4.30 & 3.66 & 0.969 \\
& YB & 45 & 20.25 & 3.33 & 3.51 & 0.964 \\
\hline \multirow{2}{*}{ ADS } & MB & $24(339.83)$ & 42.47 & 5.47 & 2.94 & 0.94 \\
& YB & $21(343.50)$ & 42.94 & 8.94 & 2.77 & 0.93 \\
\hline
\end{tabular}

Kelemen et al. (2012) reported that in European beech forests species composition changed over time within the gaps but all species found before cutting were still present in the area after 8 years. Similarly, fir-beech forest in Slovenia Kutnar et al. (2015) detected a significant increase in species richness two years after logging. In our study, according to Simpson and Shannon-Wiener index, mature stands are more diverse than young stands in the two data sets (Table 2).

\section{Accumulation curves of the understory species}

The species richness of the understory plants of mature beech stands are higher than young ones (Fig. 2). The rarefaction curves revealed very consistent patterns across the two stand types. This suggested that herb layer richness became similar after 3040 years of regeneration. The species richness was not affected significantly by shelterwood logging (Nagaike et al., 1999).

\section{Rank abundance of the understory}

When the 10 most common species on the herbaceous layer of young and mature stands are examined, it can be seen that 8 species are common in both stand types, but their rankings are different (Fig. 3). Epimedium pubigerum was the most common species in both stand types. Smilax excelsa L., Ruscus hypoglossum L. occurred in 
young beech stand in the top 10 species but did not occur in mature beech stands. On the other hand, Ornithogalum wiedemannii Boiss. and Carex sylvatica Huds. were found in the top 10 species in the mature beech stands while they were not found in young beech stands (Fig. 3).

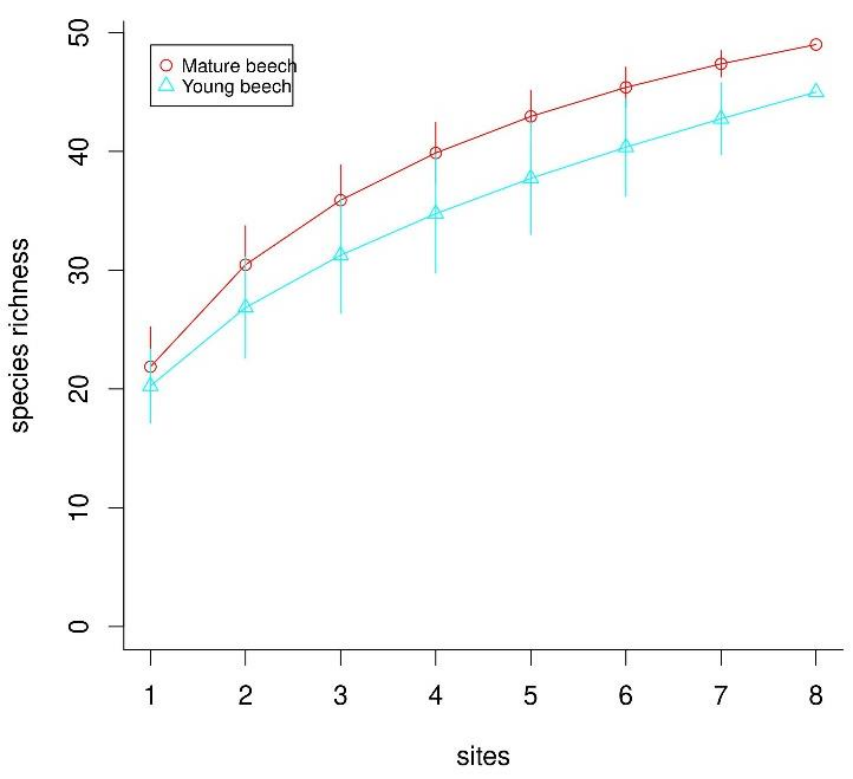

Figure 2. Species accumulation of the herb layer of beech stands in the young and mature beech stands. Rarefaction curves present the relationship between number of samples and understory species richness in beech forest stands. The whiskers show standard deviation of species richness

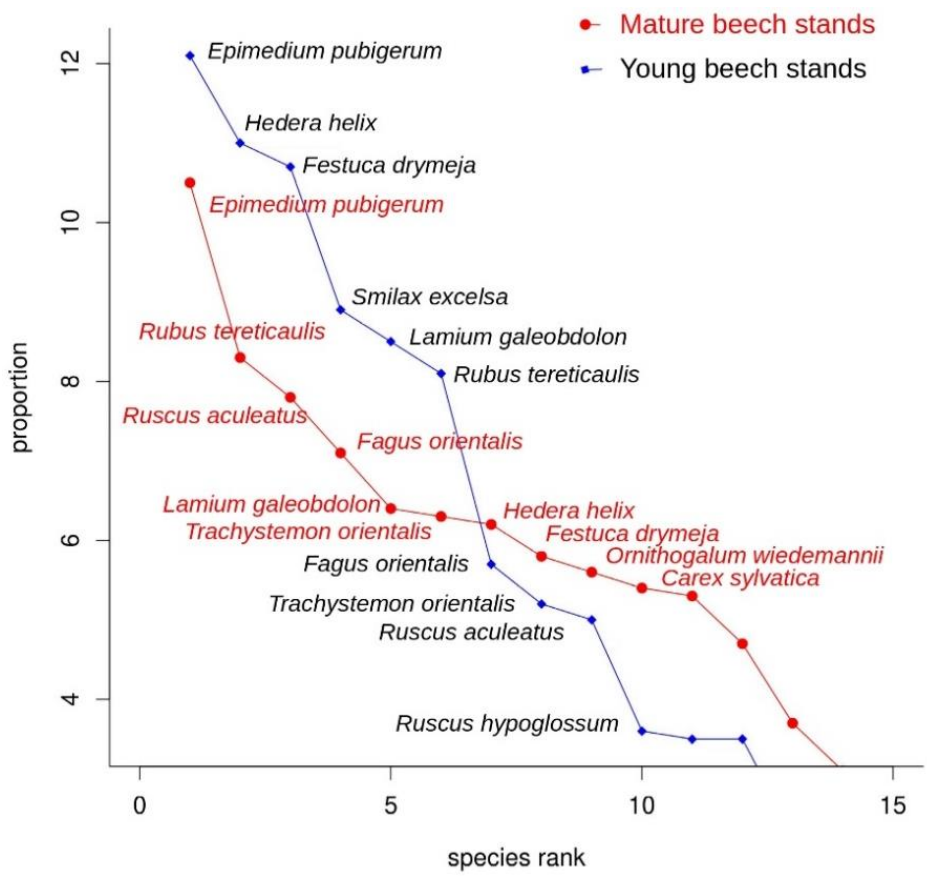

Figure 3. The herb layer species ranked in order of decreasing fidelity with respect to the two beech stand types. The proportional abundances of the species were calculated for two stand type separately 
When we look at the diversity index values (Table A2) and accumulation curves graph of the two beech stand types (Fig. 2), the values of the old stands were determined to be higher.

\section{Indicator species analysis}

Only one indicator species was determined for each stand types by the multi-level pattern analysis (Table 3). This indicates that most of typical beech forest species were found in the herbaceous layer of both young and mature beech stands. The change in species composition during the successional stages is illustrated by the results of indicator species analysis. According to indicator species analysis, young beech stands were characterized by a shade plant species Polystichum setiferum (Forssk.) Moore ex Wyon. Ornithogalum wiedemannii, which is very seldom present in successionally younger stands, was detected as an indicator of old beech stands. These results indicate that young beech stands seem to reach stabile light condition and close canopy. According to Peet and Christensen (1988), however plant species and diversity decrease through substitution of natural succession in a forest but increase in steady-state phases of forest stand development.

Table 3. The indicator herbaceous species of the beech stands

\begin{tabular}{c|c|c|c|c|c}
\hline Stand type & Indicator species & A & B & IndVal & p value \\
\hline Mature beech & Ornithogalum wiedemannii & 1.00 & 0.75 & 0.866 & $0.008^{* *}$ \\
Young beech & Polystichum setiferum & 1.00 & 0.625 & 0.791 & $0.031^{*}$ \\
\hline
\end{tabular}

The specificity (A), sensitivity (B), indicator value (IndVal) and significance ( $p$ value) are given. ' $A$ ' is the probability that the surveyed site belongs to the target site group, given that the species has been found. ' $\mathrm{B}$ ' is the probability of finding the species in sites belonging to the site group. Significance

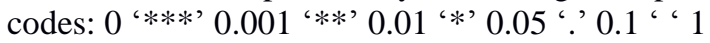

\section{Similarity of herb layer composition in mature and young stands}

According to the dissimilarity matrices, the community composition of the young and mature beech stands' herb layer was significantly different in terms of the compositional similarity (Bray-Curtis, $\mathrm{R}^{2}$ ADONIS $=0.16, \mathrm{P}=0.01$ ).

What causes the differences in composition and richness between these pure beech stands of two different successional stages? Since these areas are very close to each other, it is thought that there is not significant effect of climate and altitude factor. Previous studies have indicated the herb layer of beech stands various depending on the light conditions (Lysik, 2008). In a forest, understory light is closely dependent on the canopy structure and it is also considered the main limiting factor of understory plant richness and composition (Hill, 1979). Although understory plant species in a forest have different optimal light requirements, in beech forests, herb layer species are well adapted to low understory light conditions, or complete their life cycles before trees are completely foliated and therefore light would be less important for such species (Härdtle et al., 2003). The understory plant diversity in forests varies over time depending on stand structure. Namely, plant diversity increases rapidly in the years following the logging, then decreases when canopy closure occurs and increases slowly again depend on overstory tree density decreasing in overtime (Roberts and Gilliam, 1995; Ujházy et al., 2017). 
The results of present study showed that successional stage was the main driver of understory herbaceous species composition in even aged beech forest and Aavik et al. (2009) reported similar results in boreonemoral forests. Herbaceous plants are less sensitive to shelterwood forestry than the other species groups in a forest (Brunet et al., 2010), and therefore the shelterwood system can be suggested as a suitable method for sustainable management of plant species diversity and composition of beech stands (Poorbabei and Poor-rostam, 2009).

\section{Conclusions}

Species composition of understory vegetation in oriental beech stands was related to management intensity. At the same time, our results indicate that natural regeneration in oriental beech forests using shelterwood systems did not cause significant differences in species richness but species composition may show differences over time in these forests. Forest managers should consider the actual and potential effects of their silvicultural practices on understory vegetation diversity and composition. Although there is a small difference in diversity index and rank abundance values, there is a significant difference between the community matrices of the two stand types and it shows that two stand types are different in understory plant species and compositions.

The results showed that species richness and coverage of vascular plants were related to overstory successional stage. The results suggest that stand age influences the herb layer composition in beech stands but 16 study plots do not allow broad generalization of our results. Therefore, further studies would be necessary to acquire more knowledge about change in species composition and diversity with stand development.

Acknowledgments. This study was supported by the Scientific Research Projects Coordination Unit of Istanbul University (Project Number FBA-2016-20319).

\section{REFERENCES}

[1] Aavik, T., Püssa, K., Roosaluste, E., Moora, M. (2009): Vegetation change in boreonemoral forest during succession - trends in species composition, richness and differentiation diversity. - Annales Botanici Fennici 46: 326-335.

[2] Augusto, L., Dupouey, J. L., Ranger, J. (2003): Effects of tree species on understory vegetation and environmental conditions in temperate forests. - Annals of Forest Science 60: 823-831.

[3] Balc1, A. N., Özyuvac1, N., Özhan, S. (1986): Sediment and nutrient discharge through stream water from two experimental watersheds in mature oak-beech forest ecosystems near Istanbul, Turkey. - Journal of Hydrology 85: 31-47.

[4] Barbier, S., Gosselin, F., Balandier, P. (2008): Influence of tree species on understory vegetation diversity and mechanisms involved - a critical review for temperate and boreal forests. - Forest Ecology Management 254: 1-15.

[5] Braun-Blanquet, J. (1964): Pflanzensoziologie. Grundzüge der Vegetationskunde. Springer, Berlin.

[6] Brunet, J., Fritz, Ö., Richnau, G. (2010): Biodiversity in European beech forests - a review with recommendations for sustainable forest management. - Ecological Bulletin 53: 77-94.

[7] Davis, P. H. 1965-1985. Flora of Turkey and the East Aegean Islands. Vols. I-IX. Edinburg University Press, UK. 
[8] De Cáceres, M., Jansen, F. (2013): Package 'indicspecies' version 1.6.7. - http://cran.rproject.org/web/packages/indicspecies/index.html (accessed on 24 Nov 2018).

[9] Dufrêne, M., Legendre, P. (1997): Species assemblages and indicator species: the need for a flexible asymmetrical approach. - Ecological Monographs 67: 345-366.

[10] Durak, T. (2012): Changes in diversity of the mountain beech forest herb layer as a function of the forest management method. - Forest Ecology and Management 276: 154164.

[11] Elliott, K. J., Boring, L. R., Swank, W. T., Haines, B. R. (1997): Successional changes in diversity and composition in a clearcut watershed in Coweeta Basin, North Carolina. Forest Ecology and Management 92: 67-85.

[12] Ellum, D. S. (2009): Floristic diversity in managed forests: demography and physiology of understory plants following disturbance in southern New England forests. - Journal of Sustainable Forestry 28: 132-151.

[13] Gilliam, F. S. (2007): The ecological significance of the herbaceous layer in temperate forest ecosystems. - Bioscience 57: 845-858.

[14] Härdtle, W., von Oheimb, G., Westphal, C. (2003): The effects of light and soil conditions on the species richness of the ground vegetation of deciduous forests in northern Germany (Schleswig-Holstein). - Forest Ecology and Management 182: 327338.

[15] Hill, M. O. (1979): The Development of a Flora in Even-Aged Plantations. - In: Ford, E. D, Malcolm, D. C., Atterson, J. (eds.) The Ecology of Even-aged Forest Plantations. Institute of Terrestrial Ecology, Cambridge.

[16] Hunter, M. L. Jr. (1999): Maintaining Biodiversity in Forest Ecosystems. - Cambridge University Press, Cambridge.

[17] İster, S. I., Gökbulak, F. (2009): Effect of stand types on understory vegetation. - J. Environ. Biol. 30: 595-600.

[18] Kelemen, K., Mihók, B., Gálhidy, G., Standovár, T. (2012): Dynamic response of herbaceous vegetation to gap opening in a central European beech stand. - Silva Fennica 46: 53-65.

[19] Kindt, R., Coe, R. (2005): Tree Diversity Analysis: A Manual and Software for Common Statistical Methods for Ecological and Biodiversity Studies. - World Agroforestry Centre, Nairobi.

[20] Kutnar, L., Eler, K., Marinšek, A. (2015): Effects of different silvicultural measures on plant diversity - the case of the Illyrian Fagus sylvatica habitat type (Natura 2000). iForest - Biogeosciences and Forestry 9: 318-324.

[21] Lysik, M. (2008): Ten years of change in ground-layer vegetation of European beech forest in the protected area (Ojcow National Park, South Poland). - Polish Journal of Ecology 56: 17-31.

[22] Lorenz, M., Fischer, R., Becher, G., Mues, V., Seidling, W., Kraft, P., Nagel, H. D. (2006): Forest Condition in Europe. Technical Report of ICP Forests. - Institute for World Forestry, Hamburg. http://icp-forests.net/ (accessed on 15 December 2018).

[23] Lindenmayer, D. B., Franklin, J. F. (2002): Conserving Forest Biodiversity: A Comprehensive Multiscaled Approach. - Island Press, Washington.

[24] Nagaike, T., Kamitani, T., Nakashizuk, T. (1999): The effect of shelterwood logging on the diversity of plant species in a beech (Fagus crenata) forest in Japan. - Forest Ecology and Management 118: 161-171.

[25] OGM (General Directorate of Forestry) (2015): Forests of Turkey. - Turkey General Directorate of Forest Publications, Ankara.

[26] Oksanen, J., Guillaume Blanchet, F., Friendly, M., Kindt, R., Legendre, P.; McGlinn, D.; Peter, Minchin, R.; O’Hara, R. B.; Simpson, G. L.; Solymos, P.; Stevens, M. H. H.; Szoecs, E.; Wagner, H. (2019): vegan: Community Ecology Package. R package version 2.5-5. - https://CRAN.R-project.org/package=vegan (accessed on 10 Nov 2018). 
[27] Özhan, S., Gökbulak, F., Serengil, Y., Özcan, M. (2010): Evapotranspiration form a mixed deciduous forest ecosystem. - Water Resources Management 24: 2353-2363.

[28] Paillet, L., Bergès, L., Hjältén, J., Òdor, P., Avon, C., Bernhardt-Romermann, M., Bijlsma, R. J., De Bruyn, L., Fuhr, M., Grandin, U., Kanka, R., Lundin, L., Luque, S., Magura, T., Matesanz, S., Meszaros, I., Sebastia, M. T., Schmidt, W., Standovar, T., Tothmeresz, B., Uotila, A., Valladares, F., Vellak, K., Virtanen, R. (2011): Biodiversity differences between managed and unmanaged forests: meta-analysis of species richness in Europe. - Conservation Biology 24: 101-112.

[29] Peet, R. K., Christensen, N. L. (1988): Changes in Species Diversity during Secondary Forest Succession on the North Carolina Piedmont. - In: During, H. J., Werger, M. J. (eds.) Diversity and Pattern in Plant Communities. SPB Academic Publishing, The Hague.

[30] Poorbabaei, H., Poor-rostam, A. (2009): The effect of shelterwood silvicultural method on the plant species diversity in a beech (Fagus orientalis Lipsky) forest in the north of Iran. - Journal of Forest Science 55(8): 387-394.

[31] R Development Core Team (2017): A Language and Environment for Statistical Computing. - R Foundation for Statistical Computing, Vienna. http://www.R-project.org (accessed on 10 October 2018).

[32] Roberts, M. R., Gilliam, F. S. (1995): Patterns and mechanisms of plant diversity in forested ecosystems: implications for forest management. - Ecological Applications 5: 969-977.

[33] Saatçioğlu, F. (1970): Ten year results of natural regeneration of oriental beech (Fagus orientalis Lipsky.) by using uniform shelterwood methods in Belgrad Forests in Turkey. Journal of the Faculty of Forestry Istanbul University 20(2): 1-54.

[34] Stefańska-Krzaczek, E., Staniaszek-Kik, M., Szczepańska, K., Szymura, T. H. (2019) Species diversity patterns in managed Scots pine stands in ancient forest sites. - PLoS One 14(7): e0219620. https://doi.org/10.1371/journal.pone.0219620.

[35] Ujházy, K., Hederová, L., Málišs, F., Ujházyová, M., Bosela, M., Ciliak, M. (2017): Overstorey dynamics controls plant diversity in age-class temperate forests. - Forest Ecology and Management 391: 96-105.

[36] Yaltırık, F. (1966): Floristic Analysis of Belgrad Forest and Main Stand Composition. OGM Publications, Ankara.

[37] Yaltırik, F. (1982): Fagus L. - In: Davis, P. H. (ed.) Flora of Turkey and the East Aegean Islands. Edinburgh University Press, Edinburgh.

[38] Yaltırı, F., Akman, Y., Ketenoğlu, O. (1983): A phytosociological research in the Belgrad Forest. - Communications Faculty of Sciences University of Ankara (1): 1-9.

[39] Yilmaz, H. (2014): Fagus L. - In: Akkemik, Ü. (ed.) Trees and Shrubs of Turkey I. OGM Publications, Ankara (in Turkish).

[40] Y1lmaz, O. Y., Y1lmaz, H., Akyüz, F. (2018): Effects of the overstory on the diversity of the herb and shrub layers of Anatolian black pine forests. - European Journal of Forest Research 137: 433-445.

\section{APPENDIX}

Table A1. Presencelabsence of plants in the herb layer of 16 plots

\begin{tabular}{|c|c|c|c|c|c|c|c|c|c|c|c|c|c|c|c|c|}
\hline & \multicolumn{8}{|c|}{ Young beech stands } & \multicolumn{8}{|c|}{ Mature beech stands } \\
\hline & 1 & 2 & 3 & 4 & 5 & 6 & 7 & 8 & 1 & 2 & 3 & 4 & 5 & 6 & 7 & 8 \\
\hline Ajuga reptans $\mathrm{L}$. & & & & & & & & & 1 & & & 1 & & & & \\
\hline Arum italicum Mill. & 1 & & & 1 & 1 & & & & 1 & & 1 & & & & & 1 \\
\hline Arum maculatum L. & & & & & & & & & & & & & & 1 & & \\
\hline Asparagus acutifolius L. & & & & & & & & 1 & & & & & & & & \\
\hline
\end{tabular}




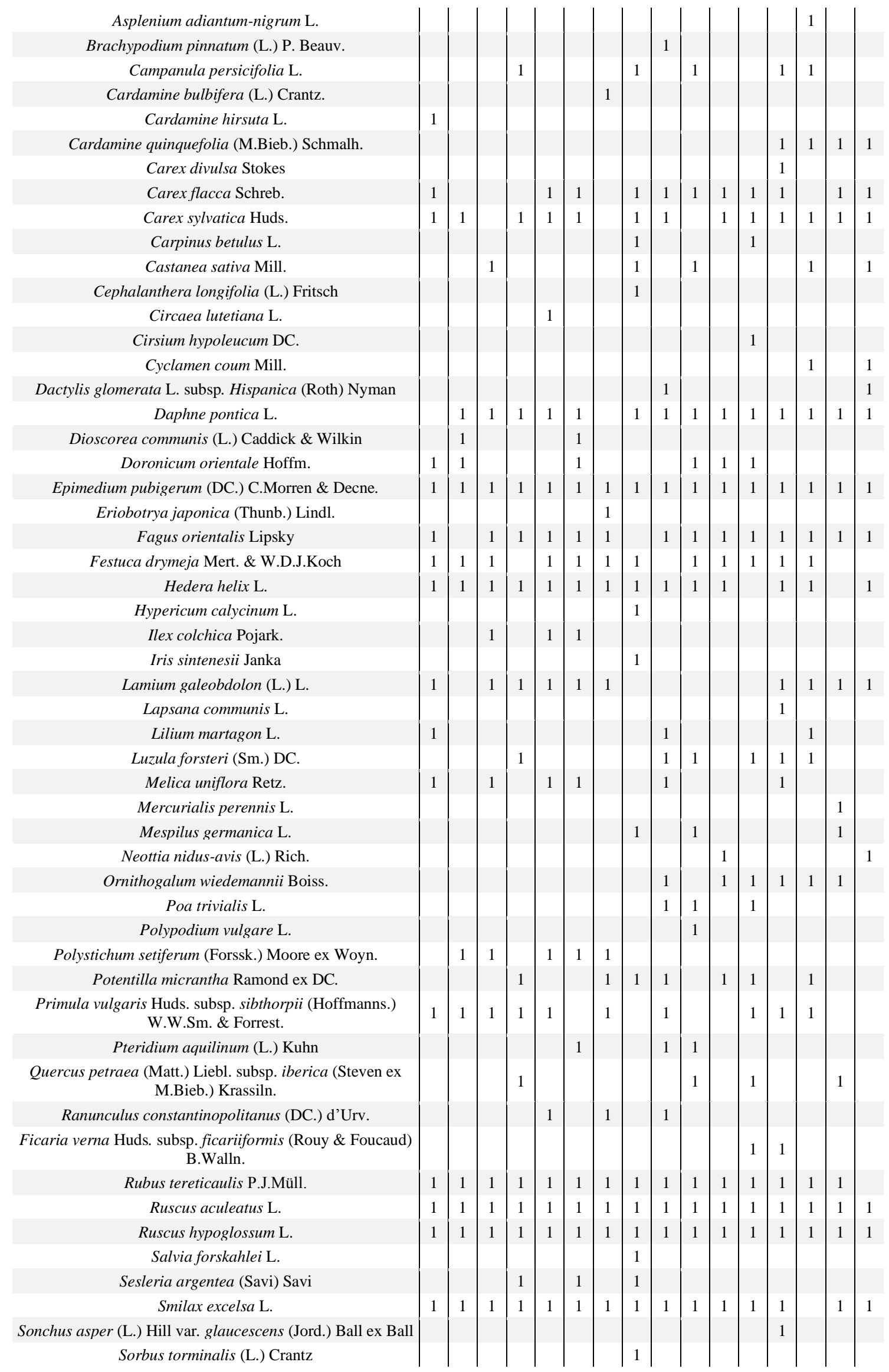


Stellaria holostea L.

Symphytum tuberosum $\mathrm{L}$.

Tilia tomentosa Moench

Trachystemon orientalis (L.) D.Don

Veronica chamaedrys L.

Viola odorata L.

Viola sieheana W.Becker

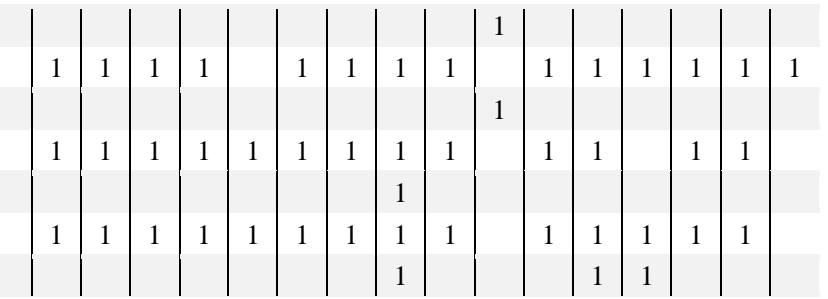

Table A2. Diversity indices of the 16 beech stands (ADS = the average of 4 subplots data)

\begin{tabular}{l|l|l|l|l}
\hline \multicolumn{2}{|c|}{ Richness } & Shannon index & Abundance (ADS) & Simpson index \\
\hline \multicolumn{5}{|c}{ Mature beech stands } \\
\hline 1 & 26 & 3.26 & 39.50 & 0.96 \\
3 & 21 & 3.05 & 39.17 & 0.95 \\
4 & 19 & 2.94 & 36.92 & 0.95 \\
5 & 25 & 3.22 & 42.83 & 0.96 \\
6 & 25 & 3.22 & 43.25 & 0.96 \\
7 & 24 & 3.18 & 44.83 & 0.96 \\
8 & 18 & 2.89 & 54.33 & 0.94 \\
\hline \multicolumn{5}{|c|}{ Young beech stands } \\
\hline 1 & 17 & 39.00 & 0.94 \\
2 & 16 & 2.77 & 37.00 & 0.95 \\
3 & 18 & 2.89 & 51.25 & 0.94 \\
4 & 20 & 3.00 & 34.17 & 0.94 \\
5 & 21 & 3.05 & 37.08 & 0.95 \\
6 & 22 & 3.09 & 47.67 & 0.95 \\
7 & 18 & 2.89 & 46.83 & 0.96 \\
8 & 27 & 3.30 & 32.50 & 0.94 \\
\hline
\end{tabular}

